Biol. Stud. 2020: 14(2); 57-68 • DOI: https://doi.org/10.30970/sbi.1402.623

www.http://publications.Inu.edu.ua/journals/index.php/biology

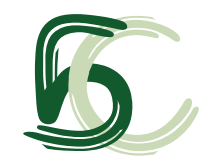

UDC: $574.5: 556: 502.3 / .7$

\title{
PHYSICOCHEMICAL AND BIOLOGICAL PARAMETERS OF DOMBROVSKE PIT LAKE - LEGACY OF OPENCAST POTASSIUM SALT MINE (KALUSH, UKRAINE)
}

\author{
A. Haydyn ${ }^{\circledR 1}$, V. Dyakiv ${ }^{2}$, N. Romanyuk ${ }^{2}$, V. Kozlovskyy ${ }^{(3 *}$ \\ ${ }^{1}$ Department of Mining and Chemical Raw Materials, Academy of Mining Sciences of Ukraine \\ 98, Stryiska St., Lviv 79026, Ukraine \\ ${ }^{2}$ Ivan Franko National University of Lviv, 4, Hrushevskyi St., Lviv 79005, Ukraine \\ ${ }^{3}$ Institute of Ecology of the Carpathians NAS of Ukraine, 4, Kozelnytska St., Lviv 79026, Ukraine \\ ${ }^{*}$ Corresponding author: e-mail: vkozlovskyy@gmail.com
}

Haydyn A., Dyakiv V., Romanyuk N., Kozlovskyy V. Physicochemical and biological parameters of Dombrovske Pit Lake - legacy of opencast potassium salt mine (Kalush, Ukraine). Studia Biologica, 2020: 14(2); 57-68 • DOI: https://doi.org/10.30970/sbi.1402.623

Complex monitoring of physicochemical and biological parameters of water bodies as holistic ecosystems allows developing their right management strategy in future. Dombrovske Pit Lake $\left(49^{\circ} 01^{\prime} 34^{\prime \prime} \mathrm{N}, 2^{\circ} 4^{\prime} 9^{\prime} 25^{\prime \prime} \mathrm{E}\right)$ was formed in an abandoned opencast potassium salt mine in 2008 , as a result of ceased mining. The lake is characterized as meromictic with the salt gradient of approximately $30 \mathrm{~g} / \mathrm{L}$ at the surface to $400 \mathrm{~g} / \mathrm{L}$ at the bottom, with the prevalence of $\mathrm{Na}^{+}, \mathrm{K}^{+}, \mathrm{Mg}^{2+}, \mathrm{Cl}^{-}$and $\mathrm{SO}_{4}{ }^{2-}$ ions. A slight heliothermal effect occurs during summer (the temperature of the hemocline is approximately $5{ }^{\circ} \mathrm{C}$ higher than that of the myxolimnion and monimolimnion). Major anions and cations $\left(\mathrm{Cl}^{-}, \mathrm{SO}_{4}{ }^{2-}, \mathrm{Na}^{+}, \mathrm{K}^{+}, \mathrm{Mg}^{2+}, \mathrm{Ca}^{2+}, \mathrm{HCO}_{3}{ }^{-}\right)$profiles are very similar to the mineralization curve, the content of microelements ( $\mathrm{Cd}, \mathrm{Ni}, \mathrm{Fe}, \mathrm{Mn}, \mathrm{Zn}, \mathrm{Pb}, \mathrm{Co})$ and $\mathrm{pH}$ also correlate with salinity. Concentrations of most heavy metals ions in the surface waters of the lake meet the Ukrainian quality standards for drinking and surface water; a small excess of Cd content compared to the Ukrainian standards is expected to disappear along with a decrease in the overall mineralization when the lake is filled to the planned level. Chlorophyll concentration $(0.5-4 \mu \mathrm{g} / \mathrm{L})$, $\mathrm{pH}$ values $(\approx 7.5)$ and dissolved oxygen content $(8-$ $12 \mathrm{mg} / \mathrm{L})$ point to a high biotic activity within the 0-5 m surface water level. Such concentrations correspond to oligotrophic lakes with a low plankton level, poor nutrient content and minimal contamination. Chl B constitutes the largest part of the total mass of chlorophyll, which indicates the predominance of green algae representatives. The relatively high proportion of $\mathrm{Chl} \mathrm{C}$ is due to the considerable biomass of diatoms and dinoflagellates, which play a crucial role in the photosynthesis of seas and oceans. Due

(C) 2020 A. Haydyn et al.; Published by the Ivan Franko National University of Lviv on behalf of Біологічні Студії / Studia Biologica. This is an Open Access article distributed under the terms of the Creative Commons Attribution License (http://www.budapestopenaccessinitiative.org and Creative Commons Attribution 4.0 License), which permits unrestricted reuse, distribution, and reproduction in any medium, provided the original work is properly cited.

ISSN 1996-4536 (print) • ISSN 2311-0783 (on-line) • Біологічні Студії / Studia Biologica • 2020 • Том 14/№2 • С. 57-68 
to low content of $\mathrm{Chl} \mathrm{A}$, the current conditions in Dombrovske Lake are not favorable for the development of blue-green algae responsible for polluted water bloom. The current stratification, physicochemical and biological characteristics of Dombrovske Lake clearly correspond to the previous forecasts about the formation of a lake with an area of approximately $100 \mathrm{ha}$, a shoreline of $8 \mathrm{~km}$, and a top freshwater layer up to $17 \mathrm{~m}$. Flooding to the final level will depend mainly on the amount of precipitation, and is expected to occur within the next 5-10 years.

Keywords: salt quarry, pit lake, heliothermal effect, biogeochemistry, chlorophyll

\section{INTRODUCTION}

Numerous lakes that appeared due to the abandoned open-cut mines occur across every continent and many of these lakes are toxic, posing risks to adjacent communities and ecosystems. On the other hand, pit lakes can bring significant benefits after remediation, providing recreational functions for adjacent communities, as well as facilitating alternative industries (aquaculture, irrigation) [14, 15, 21]. Therefore, a mine closure planning (MCP) from the first day of its operation has been progressively introduced worldwide $[11,24]$. The priority of physical and chemical approaches in pit lakes remediation projects without including the biological component leads to the creation of technical systems whereby the holistic ecosystem of the lake and its surrounding landscape is not taken into account. As a result, there is a risk that the development and evolving of a water body into a self-sustaining ecosystem will take longer and be more complicated. This thesis is best proven when negative changes in the economy result in mines being abandoned without rehabilitation. Very often, such spontaneously formed lakes without significant human interference with their functioning relatively quickly turn into useful and attractive water bodies with a high level of bio-diversity. One of such lakes was the subject of our studies - Dombrovske Pit Lake, which was formed in the place of an abandoned opencast potassium salt mine $\left(49^{\circ} 01^{\prime} 34^{\prime \prime} \mathrm{N}, 24^{\circ} 19^{\prime} 25^{\prime \prime} \mathrm{E}\right)$. The Dombrovske deposit belongs to the Kalush-Golyn group of potash ore deposits of the Carpathian potash basin. In the geological structure of the deposit, there are three main elements: potassium ore in the saline breccia, weathering rind and quaternary deposits (Fig. 1; 2). Potassium ore is composed of easily soluble halite, kainite, sylvite, less soluble langbeinite, kieserite, polyhalite, anhydrite and insoluble clay impurities (15-17\%). The weathering rind is represented by clays and sandstones containing up to $45 \%$ halite. The quaternary deposits include alluvial-dealluvial loams and sandy loams that are underlain by a gravel-pebble aquifer.

Shallow ore occurrence (20 m below the surface only) within the Dombrovske ore field was the reason for open cut mining. From the start of the quarry in 1967 and until its uncontrolled flooding in July 2008, more than 50 million $\mathrm{m}^{3}$ of the rock mass were excavated. As a result, a mine pit with the area of 64 ha and the maximum depth of $140 \mathrm{~m}$ formed. By the end of 2018, the quarry filled with water, up to $280.3 \mathrm{~m}$ above sea level, which is still $14.7 \mathrm{~m}$ below the final expected $295 \mathrm{~m}$ level (Fig. 3). The water filling occurs due to precipitation directly on the quarry area ( $70 \%$ of the total inflow of water) and groundwater inflow. Flooding to the final level will depend mainly on the amount of precipitation and is expected to occur within the next 5-10 years. The analysis and prognosis of these processes were performed during 2008-2014 [3, 7-10], and no danger to the environment was observed. The main issues of concern in the process of

ISSN 1996-4536 (print) • ISSN 2311-0783 (on-line) • Біологічні Студії / Studia Biologica • 2020 • Том 14/№2 • C. 57-68 

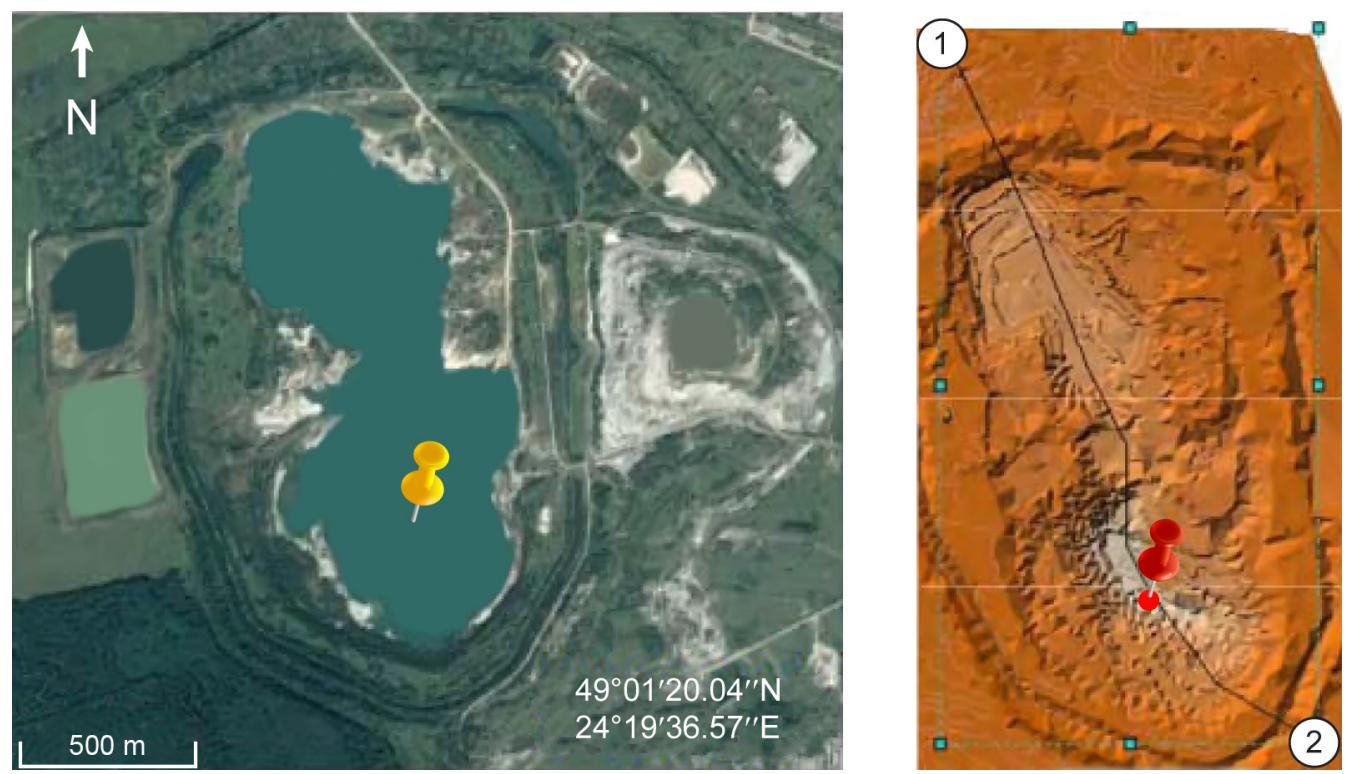

Fig. 1. Site, sampling point location and bottom profile [11] of Dombrovske Pit Lake

Рис. 1. Місце розташування, місце відбору проб і профіль дна [11] озера Домбровське
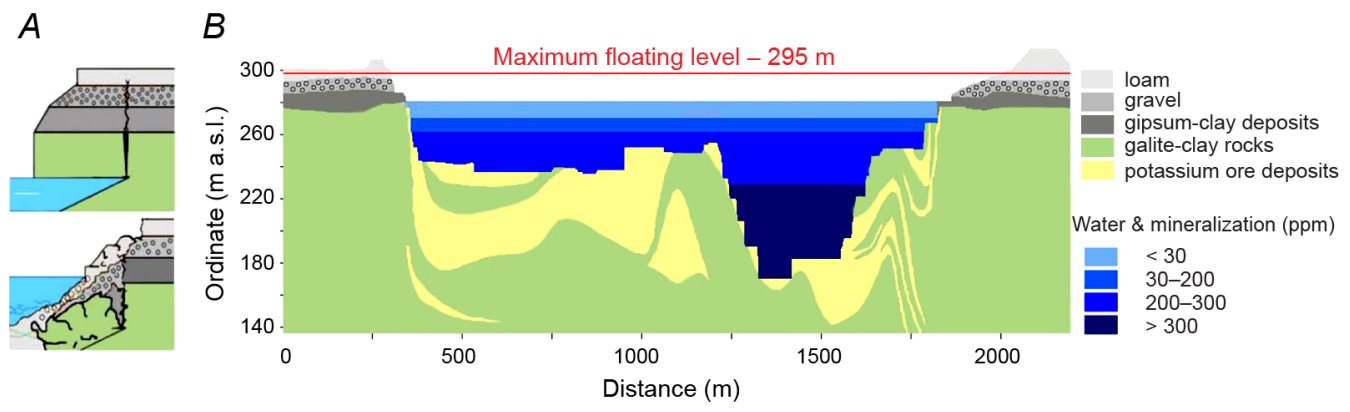

Fig. 2. Mechanism of shore formation ( $\boldsymbol{A})$, geological composition and water stratification $(\boldsymbol{B})$ of Dombrovske Pit Lake

Рис. 2. Механізм берегоутворення $(\boldsymbol{A})$, геологічний склад і стратифікація води $(\boldsymbol{B})$ озера Домбровське

Fig. 3. Flooding history and water column salinity of Dombrovske Pit Lake ( $\mathrm{g} / \mathrm{L})$

Рис. 3. Історія затоплення та солоність водяного стовпа озера Домбровське (г/л)

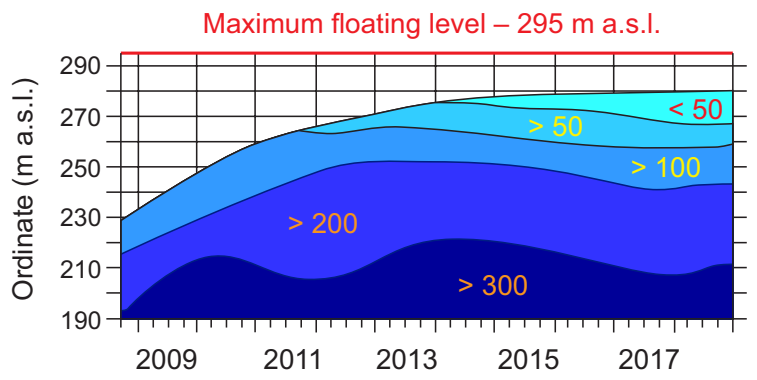

ISSN 1996-4536 (print) •ISSN 2311-0783 (on-line) • Біологічні Студії / Studia Biologica • 2020 • Том 14/№2 • C. 57-68 
flooding are 1) the stability of the slopes and 2) high mineralization of water at the level of the aquifer, with the risk of contaminating groundwater in the area adjacent to the lake and the Sivka River (the Dniester River basin). Complex monitoring of physicochemical and biological parameters of the lake as a holistic ecosystem allows estimating possible risks and developing a right management strategy in the future.

\section{MATERIALS AND METHODS}

Water sampling was performed during spring-summer 2018 from an inflatable boat at the deepest part of the pit lake (Fig. 1) using a Kemmerer type water sampler. Water profile temperature was measured.

Light conditions were determined using a Secchi disk [27].

The contents of $\mathrm{Mn}$, Fe were measured directly; $\mathrm{Zn}, \mathrm{Cd}, \mathrm{Pb}, \mathrm{Cu}, \mathrm{Co}, \mathrm{Ni}-$ after extraction with dithizone into $\mathrm{CCl}_{4}$ [2] - by a flame absorption spectroscopy; $\mathrm{Na}, \mathrm{K}$ - by a flame emission spectroscopy with atomization in an air-propane flame; $\mathrm{Ca}^{2+}$ and $\mathrm{Mg}^{2+}-$ by a complexometric titration with an EDTA; $\mathrm{Cl}^{-}$- by the Mohr method; $\mathrm{SO}_{4}{ }^{2-}-$ by precipitation with Barium; $\mathrm{HCO}_{3}{ }^{-}$- by a titration with hydrochloric acid [17].

Chlorophylls were extracted with $90 \%$ acetone from membrane filters $(0.5-\mu \mathrm{m})$ after filtering of $500 \mathrm{ml}$ volume of the lake water and analyzed spectrophotometrically at $630,645,663$, and $750 \mathrm{~nm}$ [22].

The Winkler method was used to determine dissolved oxygen content [5].

\section{RESULTS AND DISCUSSION}

Physicochemical Parameters. According to our data, the processes of shore formation and water mineralization of Dombrovske Lake are inextricably linked. Thus, at the bottom, the dissolution of the salt layers occurs until the full saturation of water, after which the dissolution and destruction of salt-containing rocks stops. In the upper layer of the quarry pit $(\approx 280 \mathrm{~m}$ a.s.l) salt dissolution occurs simultaneously with the destruction and displacement of salt-free quaternary deposits. Then, loams and gravel of the quaternary layer eventually stop the subsequent dissolution of salts by overleaping saltcontaining rocks. As a result, the destruction of the coast and the growth of water mineralization ceases (Fig. 2A). According to the forecasts, the destructive processes will spread to reach the equilibrium at a distance of no more than 30-50 m [3].

In the water mineralization data set, at least three steep segments were detected (Fig. 4). This indicates the presence of a halocline at depths of 10-20 m. A halocline is closely associated with a thermocline. The temperature maximum at the depths of 10 $20 \mathrm{~m}$ can be related to the "heliothermal" effect. The physical basis of the heliothermal energy entrapment is the salinity stratification and the sufficient amount of solar energy reaching a more salty lower water level, which functions as a heat trap [12, 13, 23]. A few centimeters thickness of the surface layer and a minimum density difference of $15 \mathrm{~g} / \mathrm{L}$ between layers are enough to begin the heating. The maximum depth of the surface layer allowing heating is determined by the light transmissibility (turbidity) of the layer. Light conditions, registered in Dombrovske Pit Lake in April 2018 and July 2019 with a Secchi disk were $\approx 3 \mathrm{~m}$ depth, indicating the euphotic zone $(\approx 1 \%$ of the amount of light available at the lake surface) of about $10 \mathrm{~m}$. It is obvious that only light transmissibility is critical for the heliothermal effect taking place in Dombrovske Lake. An excessively powerful top layer can be impenetrable for the sufficient amount of energy to

ISSN 1996-4536 (print) • ISSN 2311-0783 (on-line) • Біологічні Студії / Studia Biologica • 2020 • Том 14/№2 • С. 57-68 
achieve the heliothermal effect. At present, at least in the summer season, the heliothermal effect occurs in the waters of the lake. The temperature maximum at the depth of 15-20 $\mathrm{m}$ is maintained stable over the year since water is a very poor heat conductor; for example, one meter of non-convective water is about as good an insulator as $6 \mathrm{~cm}$ of Styrofoam [19]. Therefore, water layers of Dombrovske Lake located below and above the mesothermal layers, which are heated due to the heliothermal effect, perform the insulator function very well.
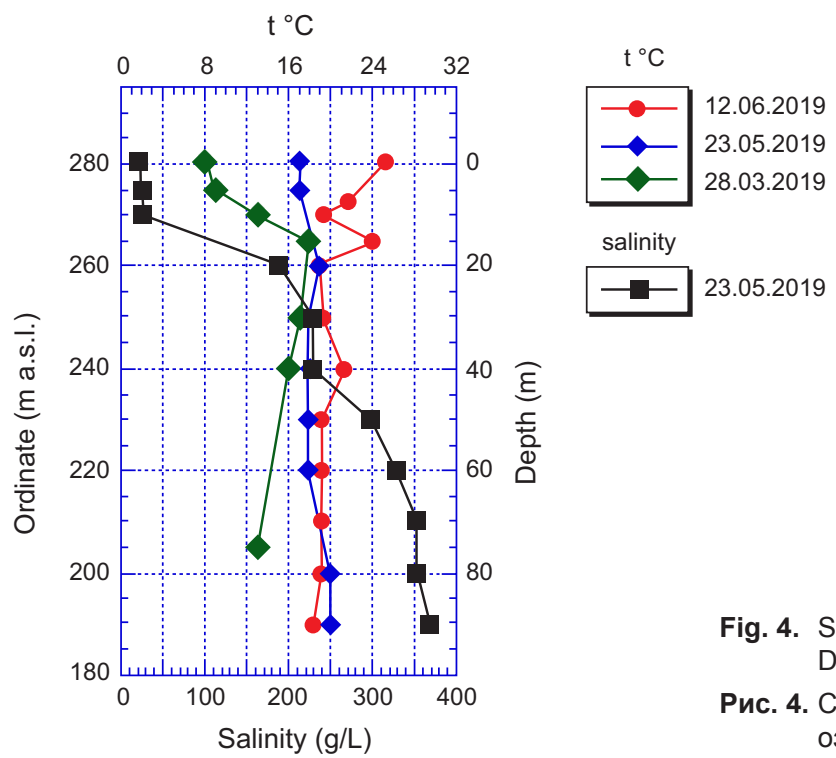

Major anions and cations $\left(\mathrm{Cl}^{-}, \mathrm{SO}_{4}{ }^{2-}, \mathrm{Na}^{+}, \mathrm{K}^{+}, \mathrm{Mg}^{2+}, \mathrm{Ca}^{2+}, \mathrm{HCO}_{3}^{-}\right)$had very similar profiles to the mineralization curve (Fig. 5) - a slight increase or stable concentrations up to the depth of $5 \mathrm{~m}$, and a sharp increase at the depths of 5-20 and 20-40 m. Microelements contents ( $\mathrm{Cd}, \mathrm{Ni}, \mathrm{Fe}, \mathrm{Mn}, \mathrm{Zn}, \mathrm{Pb}, \mathrm{Co}$ ) and $\mathrm{pH}$ also correlate with salinity (Fig. 6). However, unlike macronutrients, their concentration distribution in the water profile varies in a more complicated way - from maximum values on the surface to a minimum at the depth of $5 \mathrm{~m}$ with a repeated gradual increase to the depth of $20 \mathrm{~m}$. At the depth of 20-40 m, along with increasing of mineralization, concentrations of $\mathrm{Ni}$, $\mathrm{Fe}, \mathrm{Mn}, \mathrm{Zn}$ increase too, while the contents of $\mathrm{Cu}, \mathrm{Cd}$, Co and $\mathrm{Pb}$ (slightly) decrease. Particularly noticeable was the increase of $\mathrm{Mn}$ concentration in the lower water layers, where it was several orders of magnitude higher than the surface concentration. Such a high $\mathrm{Mn}$ content in the lake water might be caused by its high content in the geological rock of the study area. The distribution of trace elements in the upper 0-5 $\mathrm{m}$ water layer may be associated with both biotic activity and biogeochemical features of the elements.

Heavy metals content in the lake water was estimated using Ukrainian, WHO and US EPA standards $[20,26,28]$. According to the results obtained, the concentration of metals in the surface water layer of Dombrovske Lake meets the quality standards applicable in both Ukraine and the European Union (see Table). A small excess of Cd content, compared to Ukrainian standards, is expected to disappear along with a decrease in the overall mineralization when the lake is filled to the planned level.

ISSN 1996-4536 (print) • ISSN 2311-0783 (on-line) • Біологічні Студії / Studia Biologica • 2020 • Том 14/№2 • С. 57-68 

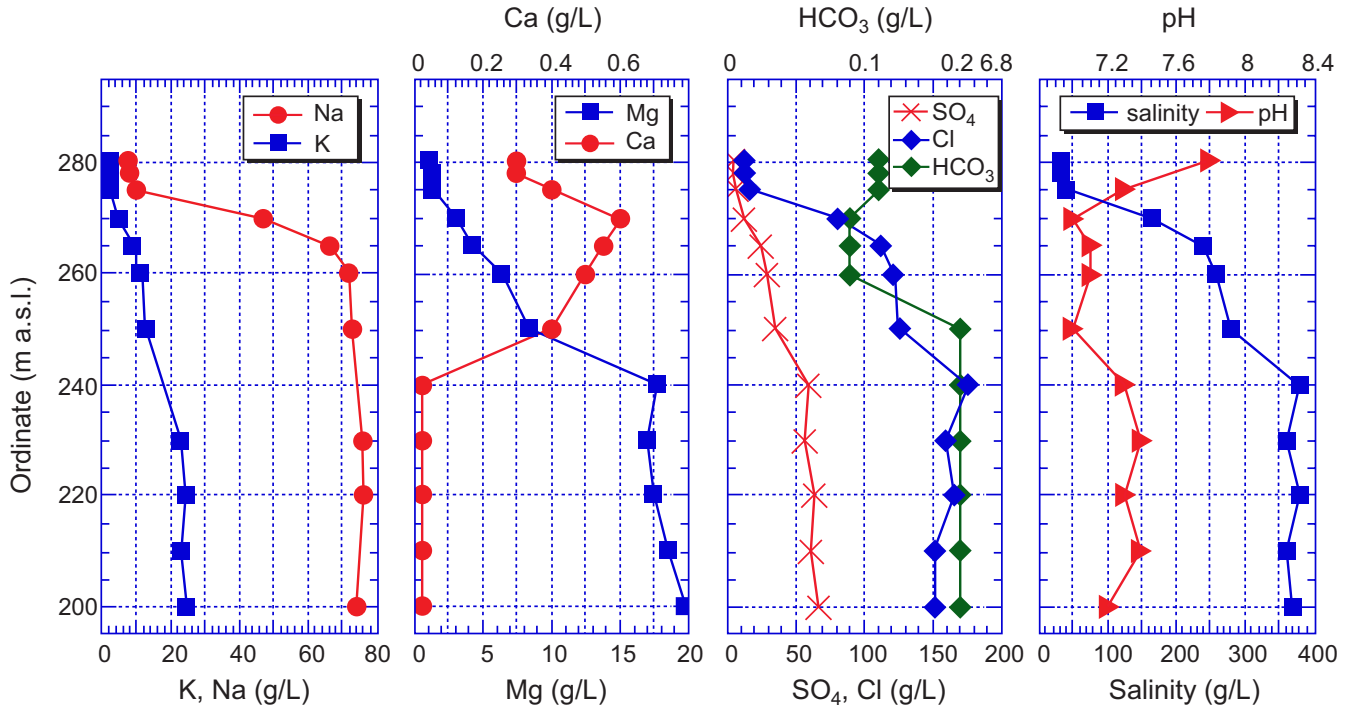

Fig. 5. Macroelements content in the water profile of Dombrovske Pit Lake, 26.06.2018

Рис. 5. Вміст макроелементів у водному профрілі озера Домбровське, 26.06.2018
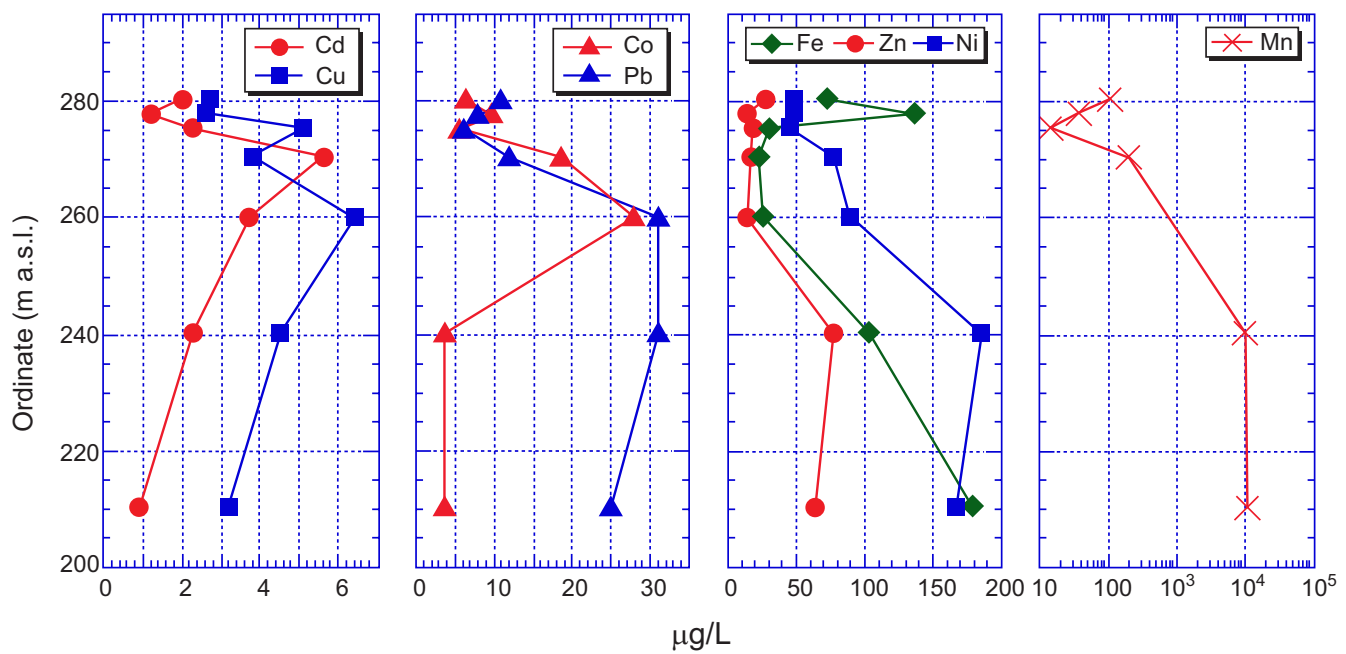

Fig. 6. Microelements content in the water profile of Dombrovske Pit Lake, 26.06.2018

Рис. 6. Вміст мікроелементів у водному профілі озера Домбровське, 26.06.2018

The increase of mineralization in the upper low-mineralized water layer due to a seasonal inversion is also impossible. Only $1 \%$ difference in the mineralization between adjacent layers is enough to prevent convection [13]. This means that the upper layer of water (mineralization $\approx 25 \mathrm{~g} / \mathrm{cm}^{3}$ ) cannot fall below the mark of $\approx 275 \mathrm{~m}$ a.s.l., where a sharp increase of mineralization $\left(\approx 50 \mathrm{~g} / \mathrm{cm}^{3}\right)$ occurs. Mixing of water under wind waves, considering the maximum wind force for this locality and the lake area, is possible at no more than $1 \mathrm{~m}$ in depth, which does not reach the boundary between fresh and saltwater [1]. Further 
filling of the lake with water to the expected level will increase the thickness of the upper low-mineralized layer and decrease its salinity. Furthermore, it will prevent mixing of adjacent water layers in the two ways mentioned above. The only possible way for the mixing of water layers in Dombrovske Lake is diffusion, but salts migration along the concentration gradient is a very long lasting process compared to the lake's geological age (hundreds and thousands of years) [25]. However, it should be noted that shoreline areas of the quarry remain incompletely remediated, which leads to additional salts leaching and salinity increase in the upper water layer.

\section{Heavy metal concentrations in the surface water samples of Dombrovske Lake vs heavy metal thresholds of Ukraine, EU, WHO $(\mu \mathrm{g} / \mathrm{L})$}

Концентрація важких металів у зразках поверхневих вод озера Домбровське та норми допустимого вмісту важких металів в Україні, ЄС, ВООЗ (мкг/л)

\begin{tabular}{|l|c|c|c|c|c|c|c|c|}
\hline \multicolumn{1}{c}{ Object } & $\mathrm{Zn}$ & $\mathrm{Cd}$ & $\mathrm{Ni}$ & $\mathrm{Co}$ & $\mathrm{Mn}$ & $\mathrm{Pb}$ & $\mathrm{Cu}$ & $\mathrm{Fe}$ \\
\hline Dombrovske Lake, 0-5 m depth & 20 & 2 & 48 & 7 & 52 & 8 & 4 & 80 \\
\hline Ukraine & 5000 & 1 & 100 & 100 & 100 & 30 & 1000 & 300 \\
\hline WHO & 3000 & 3 & 70 & N.S. & 500 & 10 & 1000 & 300 \\
EU & 5000 & 5 & 20 & N.S. & 50 & 10 & 2000 & 200 \\
SWTRV & 300 & 1.5 & 20 & N.S. & N.S. & 7.2 & 40 & N.S.
\end{tabular}

Comments: EU: The quality of water intended for human consumption by European Council Directive 98/83/EC $[4,28]$ SWTRV: Surface Water Toxicity Reference Values (SWTRVs) [26]; UA: allowable concentrations from the Ukrainian National Water Regulation [20]; N.S: Not stated

Примітки: ЄС: Якість води, призначеної для споживання людиною відповідно до Директиви Європейської Ради 98/83/€C [4, 28] SWTRV: Орієнтовні значення токсичності поверхневих вод (SWTRV) [26]; UA: Допустимі концентрації відповідно до санітарних норм діючого законодавства України [20]; N.S: Не регламентовано

The profiles of salinity, temperature, $\mathrm{pH}$ and dissolved oxygen content show characteristics common to most meromictic lakes [6].

Biological parameters. The physicochemical properties of the upper low-mineralized $0-5 \mathrm{~m}$ water layer depend not only on the characteristics of the fresh water entering the lake surface, but also on the biota of the lake ecosystem. The active involvement of biota in the ecosystem functioning can be assessed by the content of chlorophyll, dissolved oxygen and water $\mathrm{pH}$ measurements (Fig. 7). Surprisingly, our research data demonstrated the presence of chlorophyll, and, thus phytoplankton, from the water surface to the depth of $30 \mathrm{~m}$ and below, where, due to the high mineralization of water and absence of light, it should not be detected. Similar results were reported by R. Zurek et al. [29]. A high density of algal cells or their components (especially diatoms due to silica shells) and preserving properties of highly concentrated brines can be considered a possible explanation for this phenomenon. We suppose that dead algae organisms, due to their higher density, move down through the layers of concentrated brines and do not decompose, which allows detecting chlorophylls in long dead cells located at the depths, where they are not supposed to be found. Subsequently, by selecting bottom samples, it will be possible to trace the history of biota development from the beginning of the formation of the lake. The highest concentrations of chlorophyll, and therefore of phytoplankton, were revealed at the depth of 2-3 m, which corresponded to the depth of Secchi disk visibility. At the depth of $5 \mathrm{~m}$, where light intensity decreased, the concentration of chlorophyll (algae)

ISSN 1996-4536 (print) • ISSN 2311-0783 (on-line) • Біологічні Студії / Studia Biologica • 2020 • Том 14/№2 • C. 57-68 
naturally decreased too. The next chlorophyll maximum was observed at the depth of 10-20 m, which, as noted above, was caused by a sharp increase of the brine concentration, which, consequently, slowed down the movement of dead algae cells in the higher density environment. During the spring-autumn period of 2018, the total chlorophyll concentration in the surface photosynthetic water layer was in the range of 0.5-4 $\mu \mathrm{g} / \mathrm{L}$. Such concentrations of chlorophyll correspond to oligotrophic lakes with low plankton level, poor nutrient content and minimal contamination [18]. Photosynthetic activity of phytoplankton is closely related to a high oxygen content and $\mathrm{pH}$ (either by consumption of $\mathrm{CO}_{2}$ or production of $\mathrm{OH}^{-}$). Thus, the maximum possible concentration of oxygen in seawater (at a salt concentration of $\sim 35 \mathrm{~g} / \mathrm{L}, 20^{\circ} \mathrm{C}$ ) in the absence of phytoplankton is $\sim 6.5 \mathrm{mg} / \mathrm{L}$ [16]. During the vegetation season 2018 , the oxygen concentration in the upper layers of Dombrovske Lake was at the level of $8-12 \mathrm{mg} / \mathrm{L}$ and the $\mathrm{pH}$ was close to 8 units indicating a significant positive contribution of autotrophs to the gas balance formation and the creation of prerequisites for the development of a heterotrophic component of the lake ecosystem (Fig. 5, 7). The oxygen content at the depths of $10 \mathrm{~m}$ and below, during 2018, did not exceed the indicated limit of $\sim 6.5 \mathrm{mg} / \mathrm{L}$, and the $\mathrm{pH}$ dropped to values typical of the bottom layers. This indicates, despite the high concentration of chlorophyll, a lack of photosynthetic activity at the depth of more than $10 \mathrm{~m}$. During 2018, the content of chlorophyll in the upper layers of the water profile, except for the summer sampling when the index was somewhat lower, was quite stable.

17.04.2018

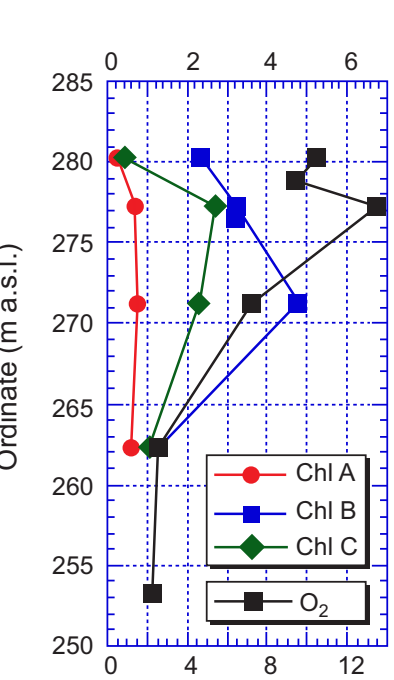

26.06.2018

03.09.2018

Chlorophyll $(\mu \mathrm{g} / \mathrm{L})$

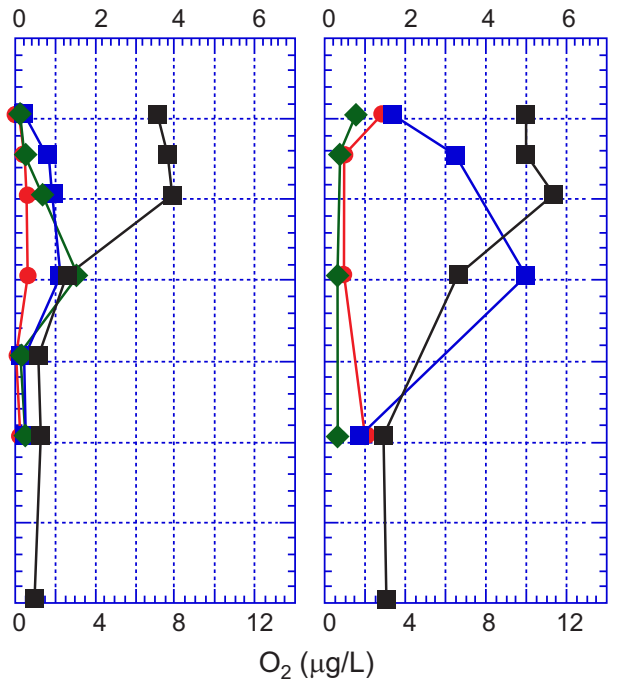

05.10 .2018

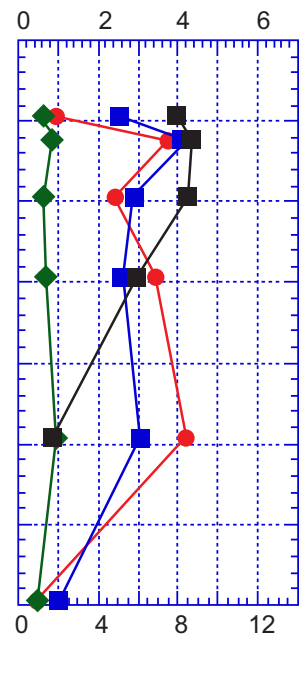

Fig. 7. Chlorophyll and oxygen content in the water profile of Dombrovske Pit Lake

Рис. 7. Вміст хлорофрілу та кисню у водному профілі озера Домбровське

On the basis of the relationship between the content of different forms of chlorophyll, we can draw preliminary conclusions about the ratio of the main systematic groups of algae. Chlorophyll a $(\mathrm{Chl} A)$ is characteristic of all photosynthetic algae, chlorophyll $b$ $(\mathrm{Chl} \mathrm{B})$ is found only in green algae (Chlorophyta), and chlorophyll $c(\mathrm{Chl} \mathrm{C})$ is only found in photosynthetic diatoms (Diatomea) and dinophyllates (Dinoflagellate). According to the

ISSN 1996-4536 (print) • ISSN 2311-0783 (on-line) • Біологічні Студії / Studia Biologica • 2020 • Том 14/№2 • С. 57-68 
results obtained, Chl B constitutes the largest part of the total mass of chlorophyll, which indicates the predominance of green algae. The relatively high proportion of $\mathrm{Chl} C$ is due to the considerable biomass of diatoms and dinoflagellates, which play a crucial role in the photosynthesis of seas and oceans. Due to the low content of Chl A, the current conditions in Dombrovske Lake are not favorable for the development of blue-green algae responsible for polluted water bloom. However, as the mineralization of water decreases rapidly enough, there are prerequisites not only for changing the functional parameters of the existing phytoplankton groups, but also for changing their species composition.

\section{CONCLUSIONS}

The development of Dombrovske Lake showed that the filling of a pit lake with rainwater concomitantly with the inflow of ground water resulted in the lake becoming meromictic. Similarly to the majority of meromictic lakes, Dombrovske Lake water profile is divided into (1) well-mixed, oxygenated, lower salinity, upper water mass (mixolimnion, 0-10 m) that usually mixes semiannually like a normal temperate dimictic lake, (2) an intermediate water mass (chemocline, 10-20 m), in which salinity increases and dissolved oxygen content decreases rapidly with depth, and (3) a lower anoxic water mass (monimolimnion, $>20 \mathrm{~m}$ ) with a relatively constant temperature and a higher salinity than the mixolimnion.

The stratigraphy of the water column by mineralization and the presence of a temperature maximum in the hemocline gives grounds to maintain that there is a "heliothermal effect" in Dombrovske Lake, at least in the summer season.

Simultaneously with the salinity reduction of the upper 0-5 m layer of the Dombrovske quarry to $30 \mathrm{mg} / \mathrm{l}$, that is almost to the level of seawater, favorable conditions for the development of biota, in particular phytoplankton, which is the basis of a complete aquatic ecosystem, were created. Chlorophyll concentration, $\mathrm{pH}$ values and dissolved oxygen content indicate the high activity of the autotrophic block of the lake ecosystem. The total content of chlorophyll gives a reason to qualify the lake as oligotrophic, i.e. a lake with a low nutrient content and a minimal contamination.

Despite its anthropogenic origin, high mineralization and relatively high content of trace elements in the lower layers of the water column, the surface water of Dombrovske Lake meets the quality standards for heavy metals content in drinking water and surface water of water bodies.

The stratigraphy, physicochemical and biological parameters of the lake that were obtained are in the framework of the previously made forecasts for the development of Dombrovske Pit Lake and its transformation into a full-fledged unique ecosystem that will have both scientific and recreational significance. It can be assumed that a lake of about 100 ha with a shoreline of $8 \mathrm{~km}$ and a top layer of fresh water up to $17 \mathrm{~m}$ has formed at the quarry site.

\section{COMPLIANCE WITH ETHICAL STANDARDS}

Conflict of Interest: The authors declare that the research was conducted in the absence of any commercial or financial relationships that could be construed as a potential conflict of interest.

Animal Rights: This article does not contain any studies with animal subjects performed by the any of the authors.

ISSN 1996-4536 (print) • ISSN 2311-0783 (on-line) • Біологічні Студії / Studia Biologica • 2020 • Том 14/№2 • C. 57-68 
1. Antonova L.N., Myhalskyy D.V., Omelchenko L. M., Chervonyy V. V., Mis'ko A. R. Evaluation of the effect of wind on the process of mixing water masses in the reservoir-cooler. Eastern European Journal of Advanced Technology, 2011; 4, 8(52): 4-7. (In Ukrainian) [Google Scholar]

2. Crompton T.R. Determination of Metals in Natural and Treated Water. CRC Press, 2001, $1280 \mathrm{p}$.

3. Dyakiv V.O. Modeling of self-isolation board, gravitational differentiation and wave mixing the formation of chemical composition of lake water by flooding during of the Dombrovsky Salt Career (Kalush). Scientific Issue Ternopil Volodymyr Hnatiuk National Pedagogical University. Series: Biology, 2015, 3-4(64): 211-215. (In Ukrainian)

[Google Scholar]

4. European Council. European Council Directive 98/83/EC - The Quality of Water Intended for Human Consumption. European Council; Brussels, Belgium: 1998.

5. Grasshoff K., Kremling K., Ehrhardt M. (Eds.). Methods of seawater analysis. 3rd completely rev. and extended Ed. Weinheim; New York; Chiester; Brisbane; Singapore; Toronto: Wiley-VCH, 1999, $634 \mathrm{p}$.

[Google Scholar]

6. Gulati R. D., Zadereev E., Degermendzhi A. G. (Eds.) Ecology of Meromictic Lakes. Ecological Studies. Springer, 2017, 405 p.

[DOI: https://doi.org/10.1007/978-3-319-49143-1; Google Scholar]

7. Haydyn A.M. Lake in the Dombrovske Potash Quarry. J. of Environmental Safety and Balanced Resources Use, 2011; 2(4): 55-62. (In Ukrainian) [Google Scholar]

8. Haydyn A.M., Dyakiv V.O. Conditions Forming of Freshwater Layer are in a Lake on Place Salt Quarry. Pryroda Zakhidnoho Polissya ta prylehlykh terytoriy, 2010; 7: 50-64. (In Ukrainian)

[Google Scholar]

9. Haydyn A.M., Dyakiv V.O. Dombrovske Lake: forecasts and facts. Ecological Safety and Balanced Use of Resources, 2012; 2(6): 72-77. (In Ukrainian) [Google Scholar]

10. Haydyn A.M., Dyakiv V.O., Chikova I.V. Kalush - revitalization program. Environmental Safety and Balanced Resources Use, 2014; 2(10): 101-107. (In Ukrainian) [Google Scholar]

11. Hrytskiv N.Z., Horlatova V.A. Study of dynamic processes of mining and industrial objects using methods of geoinformatic modelling. Geodesy, Cartography and Aerial Photography, 2014; 80: 91-100. (In Ukrainian) [Google Scholar]

12. Kalecsinszky S. Über die ungarischen warmen und heissen Koohsalzseen als natürliche Wärme-accumulatoren, sowie über die Herstellung von warmen Salzseen und Wärme-accumulatoren. Földt. Közl., 1901, 31: 409-431.

13. Kirkland D.W., Bradbury J.P., Dean W.E. The heliothermic lake - a direct method of collecting and storing solar energy. USGS Open-file Report (80-807), 1980, 126 p.

[DOI: https://doi.org/10.3133/ofr80807; Google Scholar]

14. Máthé I., Borsodi A.K., Tóth E.M., Felföldi T., Jurecska L., Krett G., Kelemen Z., Elekes E., Barkács K., Márialigeti K. Vertical physico-chemical gradients with distinct microbial communities in the hypersaline and heliothermal Lake Ursu (Sovata Romania). Extremophiles, 2014; 18: 501-514.

[DOI: https://doi.org/10.1007/s00792-014-0633-1; PMid: 24531691; Google Scholar]

15. McCullough, C.D., Lund, M.A. Opportunities for Sustainable Mining Pit Lakes in Australia. Mine Water Environ., 2006; 25: 220.

[DOI: https://doi.org/10.1007/s10230-006-0136-0; Google Scholar]

16. Millero F.J., Huang F., Laferiere A.L. Solubility of oxygen in the major sea salts as a function of concentration and temperature. Marine Chemistry, 2002, 78(4): 217-230.

[DOI: https://doi.org/10.1016/S0304-4203(02)00034-8; Google Scholar]

ISSN 1996-4536 (print) • ISSN 2311-0783 (on-line) • Біологічні Студії / Studia Biologica • 2020 • Том 14/№2 • C. 57-68 
17. Mineev V.G. Manual on Agrochemistry. M: MSU Publising, 2001, 689 p. (In Russian)

18. Oksiyuk O.P., Zhdanova G.A., Gusynskaya S.K., Golovko T.V. Assessment of the state of water bodies of Ukraine according to hydrobiological indicators. I. Plankton. Hydrobiological Journal, 1994; 30(3): 26-31. (In Russian)

19. Rabl A., Nielsen C.E. Solar ponds for space heating. Solar Energy, 1975, 17: 1-12. [DOI: https://doi.org/10.1016/0038-092X(75)90011-0; Google Scholar]

20. Sanitary rules and regulations for protection of surface water from pollution. SanPin https://zakon.rada.gov.ua/laws/show/v4630400-88?lang=en (In Ukrainian)

21. Schultze M., Boehrer B. Development of Two Meromictic Pit Lakes - a Case Study from the Former Lignite Mine Merseburg-Ost, Germany. In N. Rapantova and Z. Hrkal (eds.) Mine Water and the Environment - Proceedings of the 10th IMWA Congress (Karlovy Vary, Czech Republic, June 2-5, 2008), 2008, 611-614.

22. SCOR-UNESCO Determination of Photosynthetic Pigments in Sea Water. UNESCO Monographs on Oceanographic Methodology, Paris, 1997. 22 p.

23. Sonnenfeld P., Hudec P. Heliothermal lakes. A. Nissenbaum (Eds.) Hypersaline brines and evaporitic environments. Developments in Sedimentology. Elsevier, 1980, 28: 93-100. [DOI: https://doi.org/10.1016/S0070-4571(08)70232-2]

24. Starke L. Planning for Integrated Mine Closure: Toolkit. London, UK: International Council on Mining and Metals (ICMM). 2008. 86 p.

25. Toth D.J., Lerman A. Stratified lake and oceanic brines: Salt movement and time limits of existence. Limnology and Oceanography, 1975; 5: 715-727. [DOI: https://doi.org/10.4319/lo.1975.20.5.0715; Google Scholar]

26. US EPA Aquatic Toxicity Reference Values (TRVs) in Surface Water. Protocol. (Electronic Resource):

https://clu-in.org/download/contaminantfocus/dnapl/Toxicology/DOE_SW_tox_valuep76.pdf

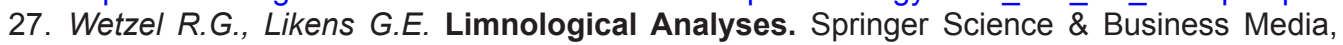 2013. 429 p.

28. WHO. Guidelines for Drinking-Water Quality (Electronic Resource): Incorporating 1st and 2nd Addenda, Vol. 1, Recommendations. WOH; Geneva, Switzerland, 2008. https://www.who.int/water_sanitation_health/dwq/fulltext.pdf

29. Żurek R., Diakiv V., Szarek-Gwiazda E., Kosiba J., Wojtal A.Z. Unique pit lake created in an opencast potassium salt mine (Dombrovska Pit Lake in Kalush, Ukraine). Mine Water Environ, 2018, 37: 456-469.

[DOI: https://doi.org/10.1007/s10230-018-0527-z; Google Scholar]

\title{
ФІЗИКО-ХІМІЧНІ ТА БІОЛОГІЧНІ ПАРАМЕТРИ ОЗЕРА ДОМБРОВСЬКЕ - КОЛИШНЬОГО КАЛІЙНОРУДНОГО КАР’ЄРУ (М. КАЛУШ, УКРАЇНА)
}

\author{
А. Гайдін ${ }^{1}$, В. Дяків ${ }^{2}$, Н. Романюк², В. Козловський ${ }^{3 *}$ \\ ${ }^{1}$ ВАТ “ГІРХІМПРОМ”, вул. Стрийська, 98, Львів 790026, Україна \\ 2 Львівський національний університет імені Івана Франка \\ вул. Грушевського, 4, Львів 79005, Україна \\ ${ }^{3}$ Інститут екології Карпат НАН України, вул. Козельницька, 4, Львів 79026, Україна \\ *Кореспондуючий автор: e-mail: vkozlovskyy@gmail.com
}

Озеро Домбровське почало стихійно формуватися на місці калійнорудного кар'єру з часу його закриття у 2008 р. До кінця 2018 р. кар'єр заповнився водою до рівня 280,3 м н.р.м., що лише на 14,7 м нижче від прогнозованого (295 м) рівня. Новоутворене озеро належить до класу мемористичних із градієнтом мінералізації від 30 г/л біля поверхні до 400 г/л у найглибшому місці з переважанням у воді $\mathrm{Na}^{+}$,

ISSN 1996-4536 (print) • ISSN 2311-0783 (on-line) • Біологічні Студії / Studia Biologica • 2020 • Том 14/№2 • С. 57-68 
$\mathrm{K}^{+}, \mathrm{Mg}^{2+}, \mathrm{Cl}^{-}$i SO${ }_{4}^{2-}$ йонів. Мінералізація з глибиною змінюється ступінчасто. Різке збільшення солоності води на глибині 10-20 м призводить до формування "геліотермального ефекту" (температура хемоклина приблизно на $5{ }^{\circ} \mathrm{C}$ вища, ніж сусідніх шарів води). Поверхневий (найменш мінералізований) шар води за вмістом важких металів ( $\mathrm{Zn}, \mathrm{Cd}, \mathrm{Pb}, \mathrm{Cu}, \mathrm{Co}, \mathrm{Ni}, \mathrm{Mn}, \mathrm{Fe})$ відповідає стандартам якості води як України, так і Європейського Союзу. Концентрація хлорофілу $(0,5-4$ мкг/л), $\mathrm{pH}(\approx 7,5)$ і вміст розчиненого кисню (8-12 мкг/л) свідчать про високу біотичну активність в 0-5 м поверхневому шарі води. Такі показники відповідають показникам оліготрофних озер із низьким рівнем розвитку планктону та мінімальним забрудненням. Найбільшу частку серед хлорофрілу становить хлорофіл $b$, що свідчить про переважання у складі фрітопланктону зелених водоростей. Відносно високий вміст хлорофрілу с відображає значну кількість діатомів і дінофлагелятів, які відіграють ключову роль у фотосинтезі морів і океанів. Низький вміст хлорофрілу а свідчить про несприятливі умови для розвитку синьозелених водоростей, які спричиняють цвітіння води у забруднених водоймах.

Поточна стратифікація водної товщі, фрізико-хімічні, біотичні параметри води відповідають попереднім прогнозам про формування на місці Домбровського кар'єру озера загальною площею близько 100 га, з береговою лінією 8 км і верхнім 17 м прісноводним шаром води. Затоплення кар'єру до прогнозованого рівня відбудеться у найближчі 5-10 років, залежно від кількості опадів.

Ключові слова: соляний кар'єр, кар'єрне озеро, геліотермальний ефект, біогеохімія, хлорофріл 